\title{
Removal of Boron from the Bittern Solution of Lake Qarun Water by Electrically Assisted Ion Exchange
}

\author{
Ibrahim Ismail, ${ }^{a, *}$ Omar Abdel-Salam, ${ }^{a}$ Fatma Barakat, ${ }^{a}$ Seif Fateen, ${ }^{a}$ \\ Ahmed Soliman, ${ }^{a}$ Masanobu Nogami ${ }^{b}$ \\ ${ }^{a}$ Department of Chemical Engineering, Faculty of Engineering, Cairo University, Giza, Egypt \\ ${ }^{b}$ Department of Electric and Electronic Engineering, Faculty of Science and Engineering, \\ Kinki University, 3-4-1 Kowakae, Higashi-Osaka, Osaka 577-8502, Japan
}

Received 27 February 2014; accepted 17 April 2014

\begin{abstract}
In this study, we investigated the use of ion exchange processes using a chelating resin, Diaion CRB02 for the removal of boron from the bittern solution left after the extraction of sodium sulfate and sodium chloride from the water of Lake Qarun, located in Egypt. The effects of parameters such as the initial boron concentration and the $\mathrm{pH}$ value on the breakthrough volume were studied using boric acid as the synthetic simulant of the bittern solution. The breakthrough capacity was shown to be directly proportional to the height of the resin bed and inversely proportional to the initial boron concentration and the feed flow rate. In addition, the optimum $\mathrm{pH}$ for boron removal was found to be 10. An electrically assisted process, which had been found to be effective for a strongly acidic cation exchange resin, was also applied to the ion exchange by taking the electric current as a parameter. However, no remarkable effect was observed, which may result from the difference in the function group between an ion exchange resin using electrostatic attractive force and a chelating resin using complex formation.
\end{abstract}

Keywords: boron removal, ion exchange, water purification, electrically-assisted ion exchange, Lake Qarun.

\section{Introduction}

The natural borate content of groundwater and surface water is usually small. The borate content of surface water can be significantly increased as a result of sewage discharges, because borate compounds are ingredients of domestic washing detergents. Naturally-occurring boron is present in groundwater

\footnotetext{
* Corresponding author. E-mail address: dr_ismail@instruchem.org, Ibrahim.ismail@eng1.cu.edu.eg
} 
primarily as a result of leaching from rocks and soils containing borates and borosilicates.

Concentrations of boron in groundwater differ widely in the range from 0.3 to $100 \mathrm{mg} \mathrm{dm}^{-3}$. The majority of the earth's boron occurs in the oceans, with an average concentration of $4.5 \mathrm{mg} \mathrm{dm}^{-3}$. The amount of boron in fresh water depends on such factors as the geochemical nature of the drainage area, proximity to marine coastal regions, and inputs from industrial and municipal effluents. Boron concentrations in fresh surface water range from 0.001 to $2 \mathrm{mg}$ $\mathrm{dm}^{-3}$ in Europe, with mean values typically below $0.6 \mathrm{mg} \mathrm{dm}^{-3}$. Similar concentration ranges have been reported for water bodies within Pakistan, Russia, and Turkey, from 0.01 to $7 \mathrm{mg} \mathrm{dm}^{-3}$, with most values below $0.5 \mathrm{mg} \mathrm{dm}^{-}$ 3 . Concentrations ranges up to $0.01 \mathrm{mg} \mathrm{dm}^{-3}$ in Japan and up to $0.3 \mathrm{mg} \mathrm{dm}^{-3}$ in South Africa surface waters [1-7].

Boron is an essential plant nutrient, although concentrations higher than $1.0 \mathrm{mg}$ $\mathrm{dm}^{-3}$ in soil can cause marginal and tip necrosis in leaves as well as poor overall growth performance. Boron concentration levels as low as $0.8 \mathrm{mg} \mathrm{dm}^{-3}$ can cause the same symptoms to appear in plants that are particularly sensitive to boron in the soil. Nearly all plants, even those somewhat tolerant of boron in the soil, will show at least some symptoms of boron toxicity when boron in the soil is greater than $1.8 \mathrm{mg} \mathrm{dm}^{-3}$. When boron in the soil exceeds $2.0 \mathrm{mg} \mathrm{dm}^{-3}$, few plants will perform well. As an ultra-trace element, boron is necessary for the optimal health of animals, although its physiological role in animals is poorly understood.

Lake Qarun is the third largest lake in Egypt and is located in the protected area of Fayoum oasis in the south west of Cairo. It is a saltwater lake, where its total salt content used to increase over years due to several reasons. To save it from the Dead Sea destiny, to improve its environment and to save its fish biota through extracting the dissolved valuable economic salts, i.e., anhydrous sodium sulfate, sodium chloride and magnesium sulfate, EMISAL, a public Egyptian company, was established in 1984. Magnesium sulfate is recovered from the bittern solution left after the extraction of sodium sulfate and sodium chloride.

Boron included in the Lake Qarun water affects the efficiency of the extraction process of magnesium salts and accordingly the quality of the extracted magnesium salts. Boron is electrolyzed when a magnesium chloride electrolyte prepared from brine concentrate contains boron or a boron compound in proportions equivalent to as little as from 15 to $60 \mathrm{mg} \mathrm{dm}^{-3}$. In this case, the magnesium metal does not coalesce readily but tends to form discrete globules dispersed in the cell melt which lowers the cell current efficiencies. Significant amounts of magnesium metal are lost in the cell smut through the process. Thus, for the production of magnesium metal on industrial scale, the magnesium chloride electrolyte should be substantially free of boron, or the level of boron in the electrolyte should be reduced sufficiently so that its adverse effects on the coalescence of the magnesium metal and cell efficiencies are minimized. As mentioned above, removal of boron from the bittern solution of Lake Qarun water is of great importance not only from the environmental aspect but also from the improvement of the quality of magnesium salts as the product. 
Several methods have been suggested for reducing the boron concentration in water to an acceptable limit [8]. Among these methods, electrodialysis [9,10] electrocoagulation [11], adsorption on different beds [12,13,14], adsorption membrane filtration (AMF) $[8,15,16]$ reverse osmosis (RO) $[17,18,19]$, ion exchange [20,21,22] and hybrid ion exchange-membrane process [23,24] seem to be the most common. A review of the removal of boron from water was recently published [25].

Ion exchange material can be grouped into five general categories: strong acid, weak acid, strong base, weak base, and chelating resin which is used in this study. Chelating resins have special functional groups containing two or more electron donor atoms that can form coordinate bonds with a single metal atom. Classes of chelating functional groups of industrial importance are phosphonic acids, amino compounds, carboxylic acids and sulfur compounds. It has been reported that chelating resins containing $N$-methylglucamine as the functional group are selective for boron [20,21].

Electrochemical ion exchange (EIX) is an advanced ion exchange process, where an exchange material has been incorporated into electrochemical system. EIX is controlled by the application of an electrode potential between the EIX electrode and a counter electrode. The combination of the EIX electrode and the counter electrode comprises the EIX cell with various configurations. Current applications of EIX have been focused on the nuclear industry, where it is important not only to keep the concentration of radio nuclides below authorized limits, but also to minimize the overall volume of any produced waste. What is unique in EIX is that the exchange process is controlled electrochemically. The use of chemicals for regeneration is, therefore, limited and it is expected to achieve large volume reduction factors since elution can be carried out within a single bed volume [26].

In the present study, removal of boron from the bittern solution left after the extraction of sodium sulfate and sodium chloride from Lake Qarun water was investigated by ion exchange processes, and the applicability of EIX was also investigated.

\section{Experimental}

Materials

Diaion CRB02 (Mitsubishi Chemical Company), a chelating resin with $N$ methylglucamine as the functional group, was used for the removal of boron. The bittern solution was supplied from EMISAL Company. The total dissolved solid, TDS, and chemical composition were analyzed by TDS meter and GBC 902 atomic absorption, respectively. This bittern solution was taken from the solar evaporation ponds in EMISAL Company, which were originally fed by Lake Qarun water without any purification or pre-treatment processes. Boric acid was used as the potential synthetic simulant of the bittern solution, considering the adsorption mechanism of boron by CRB02. Hydrochloric acid, sodium hydroxide and distilled water were used for regeneration of the resin. 


\section{Ion exchange experiments}

Standalone ion exchange experiments were performed using a lab-scale ion exchange column of $2 \mathrm{~cm}$ internal diameter. Boric acid solutions were used to perform these experiments. The effects of different parameters on the breakthrough volume were investigated. These parameters were the initial boron concentration $\left(100,140\right.$ and $\left.200 \mathrm{mg} \mathrm{dm}^{-3}\right)$, the feed flow rate $(3,4$ and 5 $\left.\mathrm{cm}^{3} / \mathrm{min}\right)$, the height of the resin bed $(3,5$ and $7 \mathrm{~cm})$, and the $\mathrm{pH}$ value $(5,7,9$, 10 and 11).

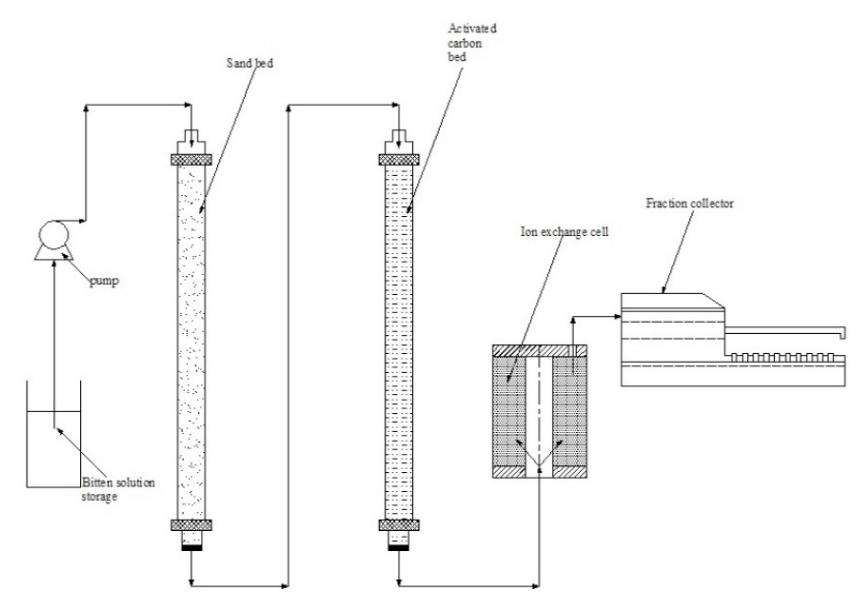

Figure 1. Illustration of the bittern solution treatment setup.

As described above, the bittern solution is so likely to contain some solid and organic impurities that it would damage the resin and cause severe fouling, if it is fed directly to the ion exchange column. Based on previous ion exchange trails conducted by EMISAL Company, the direct application of the ion exchange system was considered inappropriate due to strong fouling. In this study, therefore, for the treatment of the bittern solution, it was first filtered through a sand bed followed by an activated carbon bed, as shown in Fig. 1. After filtration, the solution was pumped after the $\mathrm{pH}$ adjustment to the ion exchange column whose bed height was $12 \mathrm{~cm}$ with a flow rate of $5 \mathrm{~cm}^{3} / \mathrm{min}$. The breakthrough curve of this solution was compared with the breakthrough curve of a synthetic solution with the same boron concentration (magnesium free solution).

\section{Electrically-assisted ion exchange experiments}

The electrically-assisted ion exchange experiments were performed using two platinum electrodes. The working electrode acts as the anode and the counter electrode acts as the cathode. The electrochemical cell consists of the following items:

(i) outer cylindrical electrode from platinum, $1.5 \mathrm{~cm}$ inner diameter with thickness of $0.1 \mathrm{~cm}$ and $10 \mathrm{~cm}$ height, which acts as an anode with total surface area of about $47 \mathrm{~cm}^{2}$;

(ii) inner cylindrical electrode from platinum, $0.8 \mathrm{~cm}$ inner diameter with thickness of $0.2 \mathrm{~cm}$ and $10 \mathrm{~cm}$ height, which acts as a cathode with total surface area of about $31 \mathrm{~cm}^{2}$; 
(iii) cell filled with $6.5 \mathrm{~g}$ of CRB02.

In this process, the synthetic boron solution was pumped through the cell and the electrical current was applied. The feed flowed from the bottom of the bed inside the perforated inner electrode, then through the resin in the annulus space between the two electrodes. The treated solution came out of the top of the cell. The schematic diagram shown in Fig. 2 represents the EIX column. The current value was adjusted using a DC power supply $(0.5,1$ and $1.5 \mathrm{~A})$ to investigate the effect of electrical current on the breakthrough volume.

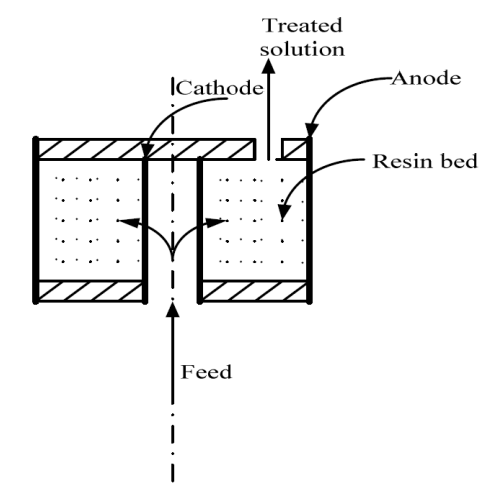

Figure 2. Electrochemical ion exchange column.

\section{Regeneration of resin}

Generally, regeneration process consists of two main steps, i.e., boron release using acid, such as $\mathrm{HCl}$ and $\mathrm{H}_{2} \mathrm{SO}_{4}$, and neutralization using basic reagent, typically, $\mathrm{NaOH}$. The boron loaded onto the resin, after breakthrough experiment, was eluted with $5 \% \mathrm{HCl}$ solution. The resin was then brought back to its original form using $5 \% \mathrm{NaOH}$ solution [27].

\section{Analysis of boron}

Concentrations of boron in the effluent stream were analyzed spectrophotometrically using the carmine acid method $\left(\lambda_{\max }: 585 \mathrm{~nm}\right)$ as described by [28].

Table 1. Analysis of the bittern solution.

\begin{tabular}{cc}
\hline Sp. Gr. & $1.235 \mathrm{~g} / \mathrm{cm}^{3}$ \\
pH & 7.5 \\
T.D.S & $340 \mathrm{~g} / \mathrm{dm}^{3}$ \\
\hline \multicolumn{3}{c}{ Component } \\
\hline $\mathrm{CO}_{3}^{2-}$ & $0.4 \mathrm{~g} / \mathrm{dm}^{3}$ \\
$\mathrm{HCO}_{3}^{-}$ & $0.6 \mathrm{~g} / \mathrm{dm}^{3}$ \\
$\mathrm{SO}_{4}^{2-}$ & $31.5 \mathrm{~g} / \mathrm{dm}^{3}$ \\
$\mathrm{Cl}^{-}$ & $185 \mathrm{~g} / \mathrm{dm}^{3}$ \\
$\mathrm{Ca}^{2+}$ & $0.15 \mathrm{~g} / \mathrm{dm}^{3}$ \\
$\mathrm{Mg}^{2+}$ & $26.0 \mathrm{~g} / \mathrm{dm}^{3}$ \\
$\mathrm{Na}^{+}$ & $83.5 \mathrm{~g} / \mathrm{dm}^{3}$ \\
$\mathrm{~K}^{+}$ & $4.5 \mathrm{~g} / \mathrm{dm}^{3}$ \\
$\mathrm{~B}$ & $0.12 \mathrm{~g} / \mathrm{dm}^{3}$ \\
Others & $8.23 \mathrm{~g} / \mathrm{dm}^{3}$ \\
\hline
\end{tabular}




\section{Results and discussion}

\section{Nature of bittern solutions}

The results of the analysis of the bittern solution are shown in Table 1. As can be seen, the solution consists of many kinds of components, including T.D.S.. The boron concentration is found to be $120 \mathrm{mg} \mathrm{dm}^{-3}$. It is known that, in aqueous solutions, dissolved boron is present as several species, depending on the concentration of boron and $\mathrm{pH}$. At low boron concentrations $\left(\leq 290 \mathrm{mg} \mathrm{dm}^{-3}\right)$, dissolved boron is mainly found as the mononuclear boron species, $\mathrm{B}(\mathrm{OH})_{3}$ and/or $\mathrm{B}(\mathrm{OH})^{4-}$, while abundance of other polynuclear ions are negligible [29]. At higher concentrations, polynuclear boron species such as $\mathrm{B}_{2} \mathrm{O}(\mathrm{OH})_{6}{ }^{2-}$ or those incorporating $\mathrm{B}_{3} \mathrm{O}_{3}$ rings such as $\mathrm{B}_{3} \mathrm{O}_{3}(\mathrm{OH})_{4}{ }^{-}, \mathrm{B}_{4} \mathrm{O}_{5}(\mathrm{OH})_{4}{ }^{2-}$, and $\mathrm{B}_{5} \mathrm{O}_{6}(\mathrm{OH})_{4}{ }^{-}$are formed with an increase in $\mathrm{pH}$ [30]. These facts suggest that only the mononuclear species $\mathrm{B}(\mathrm{OH})_{3}$ and $\mathrm{B}(\mathrm{OH})_{4}{ }^{-}$are expected to be present in the bittern solution and that boric acid could be used as a synthetic simulant of the bittern solution.

In our preliminary study, the kinetics of the process of boron removal by CRB02 using boric acid by batch mode operations was studied and the equilibrium halftime for boron removal was found to be between 20 and $30 \mathrm{~min}$. Moreover, a good fitting to the sorption mechanism described by pseudo-second-order mechanism was obtained. This agrees with the previous reports by [27, 31].
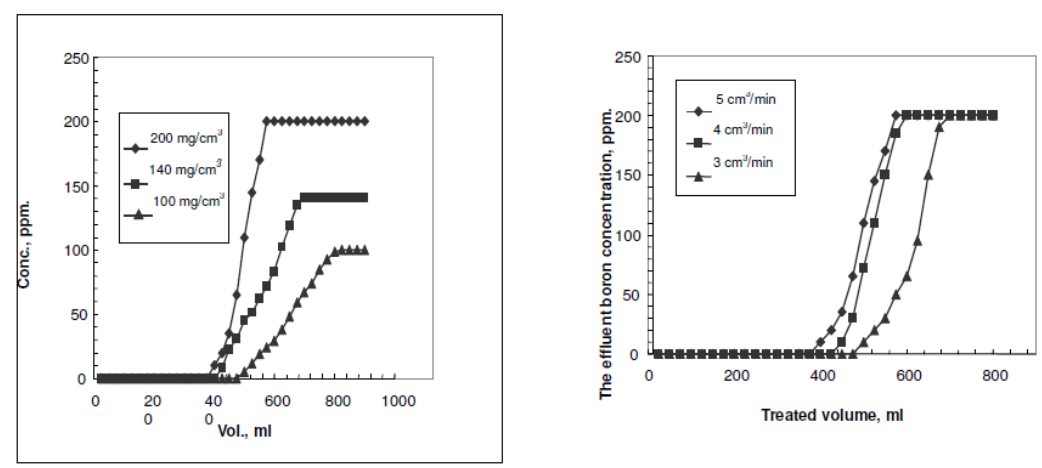

[a] Effect of the initial boron concentration.

[b] Effect of the feed flow rate .
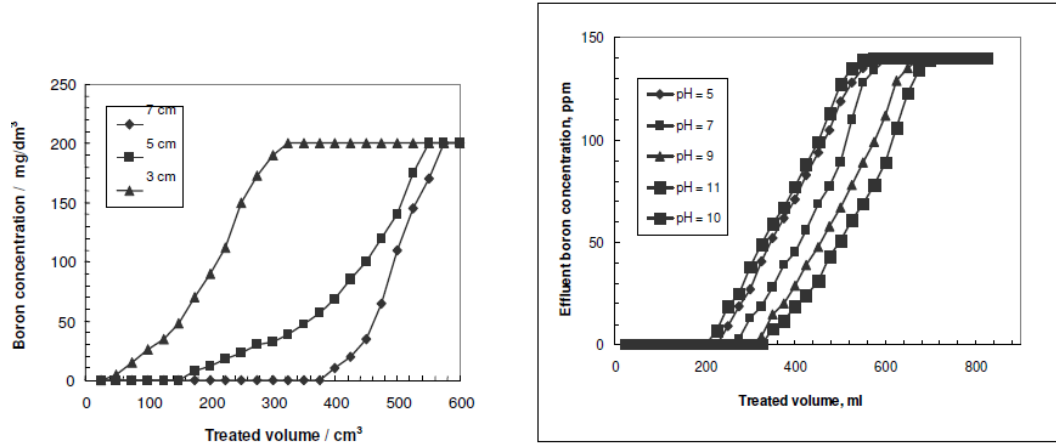

Figure 3. Effect of different parameters on standalone ion exchange breakthrough curves. 


\section{Ion exchange system}

Effect of initial boron concentration on breakthrough volume

The treated volume at the breakthrough point increases when the initial boron concentration decreases, as shown in Fig. 3[a]. Since the chelating resin used as the exchange fixed bed was of fixed amount and capacity, it removed a fixed amount of boron ions. Thus, increasing the initial boron concentration in the feed decreases the volume treated at the breakthrough point.

\section{Effect offeed flow rate on breakthrough volume}

The increase in the flow rate decreases the volume treated at the breakthrough point, as depicted in Fig. 3[b]. The capability of chelating resin to remove boron ions from influent solution decreased as a result of the increase in the feed flow rate, due to the decrease in the residence time. This agrees with the results previously reported for boron removal by Dowex (XUS 43594.00) resin [24] and by CRB02 [32].

\section{Effect of resin bed height on breakthrough volume}

The increase in the resin bed height increases the volume treated at the breakthrough point, as shown in Fig. 3[c]. The higher the resin bed, the more the resin quantity, hence, the more active sites capable of removing boron ions. These results agree with those obtained using another chelating resin, Amberlite IRA 743. The performance of boron removal by this resin increased upon increasing the batch ratio of resin to boron, and decreasing the initial concentration of boron in the solution [33].

\section{Effect of $\mathrm{pH}$ value on breakthrough volume}

The adsorption of boron by the chelating resin with $N$-methylglucamine as the functional group is in principle achieved by the complexation. CRB02 could be described as a macroporous and crosslinked polystyrene resin functionalized with $\mathrm{N}$-methyl-D-glucamine (1-amino-1-deoxy-D-glucitol; NMG) group. Boric acid reacts with compounds possessing multihydroxyl groups, namely polyols, to form a variety of borate esters, in accordance with Eq. (1)

$$
\mathrm{B}(\mathrm{OH})_{3}+3 \mathrm{ROH} \leftrightharpoons \mathrm{B}(\mathrm{OR})_{3}+3 \mathrm{H}_{2} \mathrm{O}
$$

where $\mathrm{R}$ is a hydrocarbon group. The formed esters rapidly dissociate to release protons. Thus, the amount of acidification produced upon the addition of the polyols is proportional to the extent of ester formation, which is used for monitoring the reaction. The stability of the borate complex formed strongly depends on the type of diol used. A strong complex is formed when the diol used involves the hydroxyl groups oriented in such a way that they accurately match the structural parameters required by the tetrahedrally-coordinated boron. The functional group of CRB02 has a tertiary amine end and a polyol end, and the adsorption of boric acid by CRB02 is represented as shown in Fig. 4. The role of the tertiary amine in the functional group is to neutralize the proton brought by the formation of tetra borate complex. Amine protonation shown in Eq. (2) is 
critical to prevent the decrease of $\mathrm{pH}$ by proton released from the dissociation of borate esters.

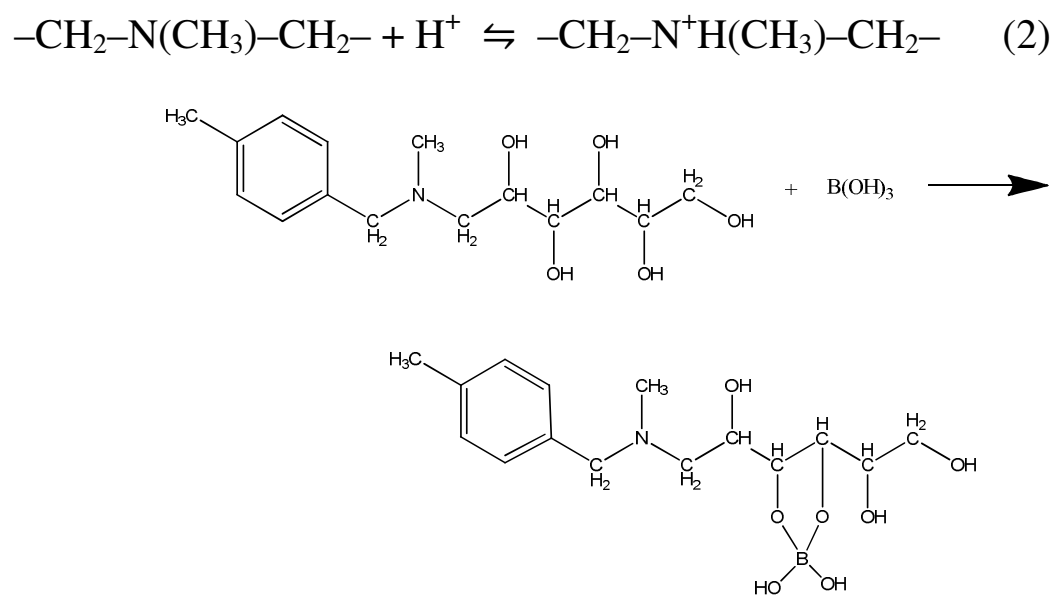

Figure 4. Chelating of boron on the resin structure.

As far as hydroxyl groups are concerned, there are 5 hydroxyl groups in $N$ methyl-D-glucamine. This allows the formation of a strong complex with boron and improves the possibility of complexation by offering several sites for boron. The optimum $\mathrm{pH}$ value for boron removal is found to be 10, as shown in Fig. $3[\mathrm{~d}]$. It has been reported that the optimum $\mathrm{pH}$ values for boron removal are different from one resin to another, ranging from 8.5 to 9.5 [34, 35]. The removal process and reactivity of boron in solutions were influenced by $\mathrm{pH}$ in a significant way. The $\mathrm{pH}$ value is an important control parameter for boron removal process. The amount of boron adsorbed depends on the distribution of $\mathrm{B}(\mathrm{OH})_{3}$ and $\mathrm{B}(\mathrm{OH})_{4}{ }^{-}$which are controlled by the $\mathrm{pH}$ value of the solution. Boric acid is a very weak acid with a $\mathrm{pKa}$ value of 9.2. At a lower $\mathrm{pH}$ than 7 , boron is present in its non-dissociated form (boric acid) and at a $\mathrm{pH}$ higher than 10.5, it is present in the dissociated borate form. The exact percentage of boric acid and borate in any aqueous system is basically dependent on $\mathrm{pH}$. The monovalent anion of borate, $\mathrm{B}(\mathrm{OH})_{4}{ }^{-}$, dominates at higher $\mathrm{pH}$ while non-ionized boric acid $\mathrm{B}(\mathrm{OH})_{3}$ at lower $\mathrm{pH}$. The dissociation of boric acid in water can be described as follows:

$$
\mathrm{B}(\mathrm{OH})_{3}+\mathrm{H}_{2} \mathrm{O} \leftrightarrow \mathrm{B}(\mathrm{OH})_{4}{ }^{-}+\mathrm{H}^{+} \quad \mathrm{pKa}=9.2 \text { at } 25{ }^{\circ} \mathrm{C}
$$

The breakthrough properties of the real bittern solution and the synthetic simulant solution adjusted at $\mathrm{pH}=10 \mathrm{using}$ sodium hydroxide were compared. As depicted in Fig. 5, the breakthrough curves of the two solutions are almost identical. This indicates that CRB02 is not affected by the presence of any other ions in the solution. 


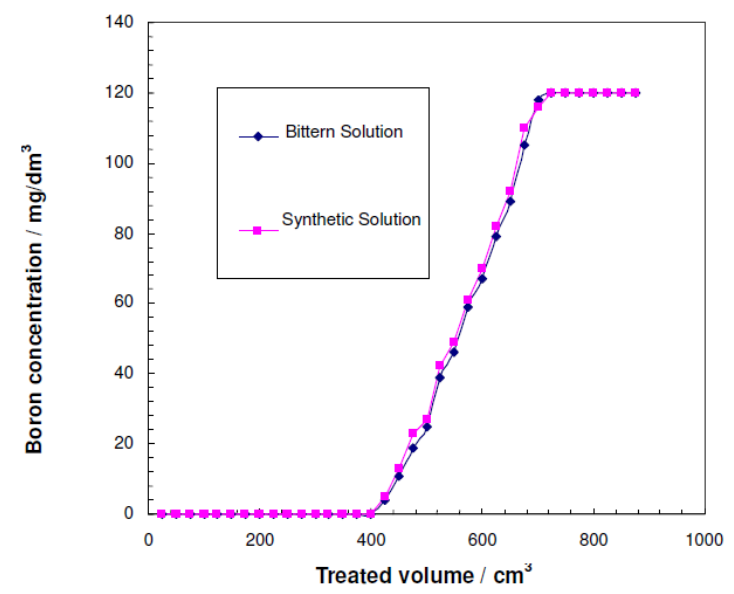

Figure 5. Comparison of boron breakthrough of synthetic solution and bittern solutions.

\section{Electrically-assisted ion exchange system}

The breakthrough curves are slightly affected by the application of the electrical current, as shown in Fig. 6. However, the application of the electrical current does not affect the breakthrough point in a remarkable way. In case of nickel removal using electrically assisted ion exchange process, where Purolite C150S strong acid cation exchange resin was utilized, the application of the electrical current remarkably affected the breakthrough point. Namely, applying the electrical potential enhanced the nickel removal at breakthrough point by $12.7 \%$ and $2.5 \%$ at the flow rates of 240 and $500 \mathrm{~cm}^{3} / \mathrm{h}$, respectively. Moreover, the sorption of $\mathrm{Cs}$ by nickel hexacano ferrate, NiHCF, ESIX process was also a successful application for the electrical assisted ion exchange process [36]. This discrepancy in electric current effect on boron removal by CRB02 and nickel removal by Purolite C150S and Cs removal by nickel hexacano ferrate ESIX process may be attributed to the difference in the sorption mechanism resulting from the difference in the function between an ion exchange resin using electrostatic attractive force and a chelating resin using complex formation. According to the mechanism shown by Rassat et al. for electrically assisted ion exchange uptake, the negative electron charges applied electrically to the ion exchange layer in the working cathode are the main driving force for the enhancement process. This negative electron reduces the $\mathrm{Fe}(\mathrm{III})$ atom in the $\mathrm{NiHCF}$ and creates an electrical field attracted the Cs ion towards the cathode. In case of nickel sorption by Purolite C150S, the electrical field attracted the $\mathrm{Ni}$ ions toward the working electrode as well and enhanced the sorption process. In our current case and according to the boron uptake mechanism by CRB02 shown in Fig. 4, boron atom is attached to two oxygen atoms from the resin and another two oxygen atoms from the hydroxyl groups through chelating mechanism. Therefore, the boron atom has so high electron densities, which minimizes the effect of the cathodic potential applied to it. The coordination of the boron atom in solution with different hydroxyl negative groups also minimizes the effect of the electric field applied to the system. Based on these findings, it is not recommended to use chelating resins in electrically assisted ion exchange processes. 


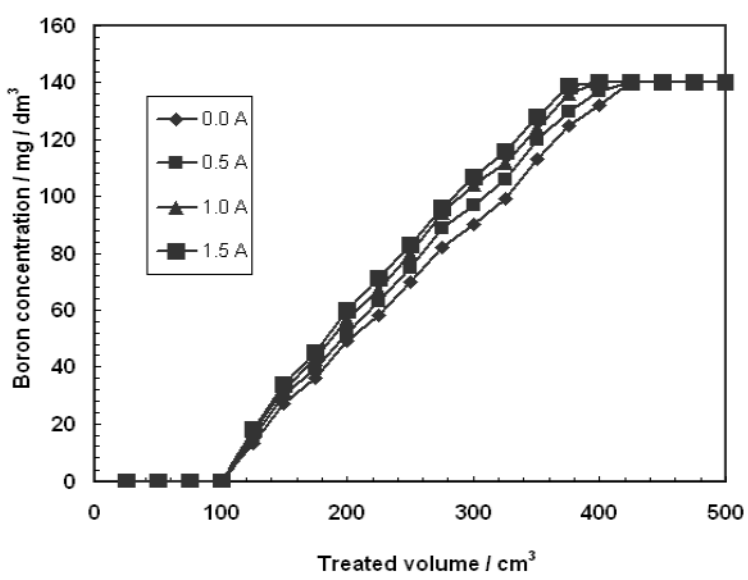

Figure 6. Effect of the electric current on electrically enhanced ion exchange breakthrough curves.

\section{Regeneration of resin}

Fig. 7 shows the boron concentration in the effluent solution as a function of $\mathrm{HCl}$ volume. Badruk et al. achieved 100\% elution of boron from loaded CRB02 resin using $\mathrm{HCl}[32,37]$, compared the breakthrough capacity of the boron removal process after regeneration by three different methods and clarified that regeneration with $\mathrm{H}_{2} \mathrm{SO}_{4}$ followed by $\mathrm{NaOH}$ gives an increased resin adsorption capacity in comparison to regeneration with $\mathrm{H}_{2} \mathrm{SO}_{4}$ solely. This can be explained by the fact that the gross uniformity of the chemical potential of the resin is improved by $\mathrm{NaOH}$. Although the resin used in his experiment is not CRB02, Rohm and Haas Amberlite IRA 743, it has the same $N$-methylglucamine function group like $\mathrm{CRB}$ 02, which allows us to expect the same performance.

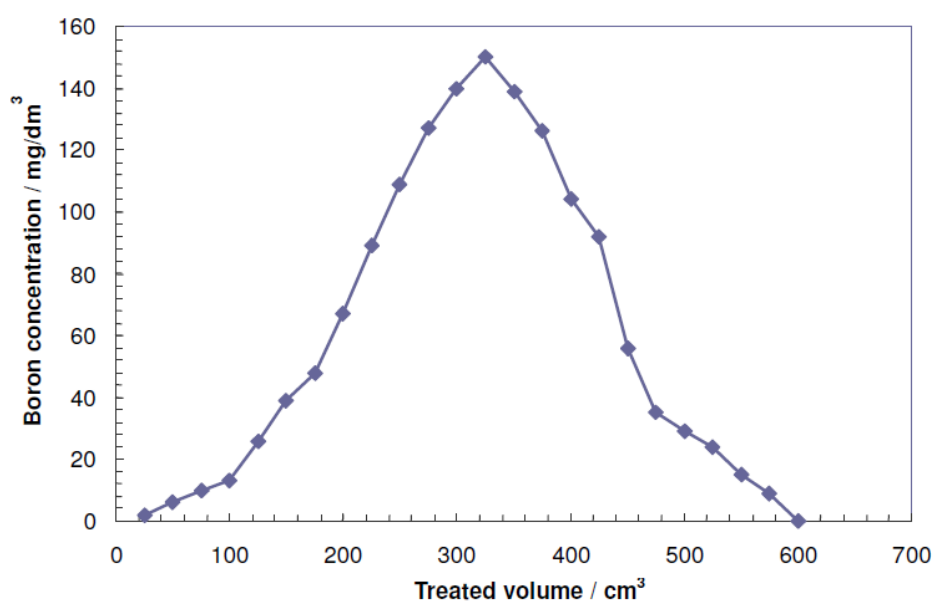

Figure 7. Elution profile of boron.

\section{Conclusions}

The performance of the chelating resin, Diaion CRB02, was investigated under different operating conditions. The breakthrough volume was found to be inversely proportional to the initial boron concentration and the feed flow rate and directly proportional to the height of the resin bed. The optimum $\mathrm{pH}$ value was found to be 10 . The application of the electrical current was found to be of 
no remarkable effect on the breakthrough volume due to the chelating mechanism of the resin function group. Based on this, it is not recommended to use chelating resins in electrically assisted ion exchange processes. The system was utilized successfully for the removal of boron from the bittern solution of EMISAL Company.

\section{Acknowledgements}

The authors would like to acknowledge EMISAL Company for their support and the supply of the bittern solution.

\section{References}

1. Nielsen FH, Gallagher SK, Johnson LK, et al. J Trace Elem Exp Med. 1992;5:237.

2. Penland JG, Dietary boron, brain function, and cognitive performance, Environ Health Perspect. 1994;102:65.

3. Price CJ, Strong PL, Marr MC, et al. Toxicol Sci. 1996;32:179.

4. WHO Library Cataloguing in Publication Data Boron. Environmental Health Criteria; 204. 1996.

5. Argust P. Biol Trace Elem. 1998;66:131.

6. Rayner-Canham G. Descriptive inorganic chemistry. MacMillan;2003.

7. Kotz JC, Treichel PM, Townsend JR. Chemistry \& chemical reactivity. Cengage Learning;2011.

8. Bryjak M, Wolska J, Soroko I, et al. Desalination. 2009;241:127.

9. Turek M, Bandura B, Dydo P. Desalination. 2008;223:17.

10. Banasiak LJ, Schäfer AI. J Membr Sci. 2009;334:101.

11. Yilmaz AE, Boncukcuo R, Kocakerim MM, et al. J Hazard Mater. 2008;153:146.

12. Choi WW, Chen KY. Environ Sci Technol. 1979;13:189.

13. Köse TE, Demiral H, Öztürk N. Desalination Water Treat. 2011;29:1.

14. Kıpçak İ, Özdemir M. Chem Eng J. 2012;189-190:68.

15. Bryjak M, Wolska J, Kabay N. Desalination. 2008;223:57.

16. Oo MH, Song L. Desalination. 2009;246:605.

17. Prats D, Chillon-Arias MF, Rodriguez-Pastor M. Desalination. 2000;128:269.

18. Hyung H, Kim JH. J Membr Sci. 2006;286:269.

19. Öner ŞG, Kabay N. Desalination, 2011;283:10.

20. Senkal BF, Bicak N. React Funct Polym. 2003;55:27.

21. Jacob C. Desalination. 2007;205:47.

22. Samatya S, Tuncel SA, Kabay N. Desalination. 2014. In press. 10.1016/j.desal.2014.01.029

23. Guo WS, Shim WG, Vigneswaran S, et al. J Membr Sci. 2005;247:65.

24. Ipek IY, Kabay N, Yuksel M, et al. Chem Eng Comm. 2008;196:277.

25. Wang B, Guo X, Bai P. Colloids Surf A: Physicochem Eng Asp. 2014;444:338. 
26. Bridger NJ, Jones CP, Neville MD. J Chem Technol Biotechnol. 1991;50:469.

27. Kabay N, Sarp S, Yuksel M, et al. Desalination. 2008;223:49.

28. Hatcher JT, Wilcox LV. Analyt Chem. 1950;22:567.

29. Su C, Suarez DL. Environ Sci Techn. 1995;29:302.

30. Power PP, Woods WG. Plant Soil. 1997;193:1.

31. Kabay N, Sarp S, Yuksel M, et al. React Funct Polym. 2007;67:1643.

32. Badruk M, Kabay N, Demircioglu M, et al. Sep Sci Technol. 1999;34:2981.

33. Simonnot MO, Castel C, Nicolai M, et al. Water Res. 2000;34:109.

34. Boncukcuoğlu R, Yllmaz AE, Kocakerim MM, et al. Desalination. 2004;160:159.

35. Öztürk N, Köse TE. Desalination. 2008;227:233.

36. Rassat SD, Sukamto JH, Orth RJ, et al. Sep Purif Technol. 1999;15:207.

37. Nadav N. Desalination. 1999;124:131. 